\title{
Performance and Competitiveness of Private Universities in Bengkulu Province
}

\author{
Arifah Hidayati \\ Universitas Bengkulu, Indonesia \\ arifah2020@yahoo.com
}

\begin{abstract}
The purpose of this study is to analyze the relationship between variables of market orientation, innovation orientation, and organizational learning orientation to the performance and competitiveness of private universities in Bengkulu province. The population of this study is the leaders of private universities, deans, and heads of study programs from 17 accredited Private Universities with a sample of 127 respondents. This research was conducted using a quantitative approach with survey methods. The design of this study is descriptive and verification research to analyze the causality between the studied variables. Data processing used descriptive analysis techniques and hypothesis testing with the Structural Equation Model (SEM). The results showed that market orientation, innovation orientation, and learning orientation had a significant effect on the performance and competitiveness of private universities. To increase the performance and competitiveness, leaders must be able to create an appropriate market orientation model and focus on service quality by considering the internal conditions of private universities. Policymakers should also make improvements or develop their learning orientation through education and training, and develop themselves in the fields of knowledge and technology. This is done as a material evaluation for development or innovation related to the revitalization of private universities to have the ability to adjust the progress of the age (future proof).
\end{abstract}

Keywords. market orientation, innovation orientation, learning orientation, institutional performance, and competitive advantage

\section{Introduction}

University is one of the main pillars of development in developing the quality of human resources. Due to the importance of the role of education, it is mandated in the 1945 Constitution that every citizen has the right to receive education and teaching in which the government makes a national education system whose implementation is regulated in the law. Universities are expected to be the center of the organization and development of the higher level of education as well as the maintenance, guidance and development of science, technology, and / or art as a scientific society that can improve the quality of society life, nation, and state.

Considering the number of population and the growth rate of educational needs, it is impossible for the government to provide education for the community as a whole, because of that, the participation of the private sector is needed in providing universities (De Vaus, 2002; Zikmund, 2000). In terms of quantity, the existence of private universities is more than state universities.

The increasing competition in universities in Indonesia requires an internal change for each organization in preparing competitive strategies so that they can survive in an environment that is full of uncertainty. Private universities in Bengkulu Province also face relatively serious challenges, because the quality of conditions and abilities of private universities in Bengkulu Province have not been able to meet the standards set by the National Accreditation Board for Higher Education (BAN-PT) fully. For this reason, Universities need to implement strategies that are flexible to the development and changes that occur so that the capability to manage and utilize limited resources is 

competitive advantage continuously through a unique set of resources owned by the company (Chuang, 2004).

Porter (1993) defines competitiveness as a benefits strategy of companies that collaborate to compete more effectively in a market place. Thus, the old market and new market can be dominated by the company. Day and Wensley (1998) explains that achieving competitiveness is based on two factors, namely resource superiority and position superiority. The complexity and dynamics of the environment, has driven companies to strengthen strategies with some concepts that focus on customers intensely hence they can still access their markets and ensure sustainable growth.

According to Narver and Slater (1995, p. 134). Companies that have made market orientation as an organizational culture will focus on the needs of external markets and market demand as the basis for developing strategies that will determine company performance. Because of that, commitment and participation of all members of the organization which will be continuous learning for the organization are required therefore it will create more value for customers. Due to that, it is necessary for companies to improve the ability of companies in the aspects of organizational learning which is one way to improve the performance of institutions. Previous studies state that organizational learning is the key to organizational success in the future (Luke, 1996). Besides that, previous studies did not explain further about the effect of the market orientation process, innovation as competitiveness on the performance of universities. This aspect is more interesting to be researched.

Besides a market-oriented culture, innovation is needed for having the ability and competence to adapt to rapid changes called learning. Baker and Sinkula (1999) define innovation as a company's mechanism to adapt in a dynamic environment so creating service performance that satisfies customers, where the concept of innovation is distinguished in technical innovation and administrative innovation. Product innovation focuses on fulfilling the market demand, so product innovation is a competitive advantage factor for companies (Han et al., 1998). High-quality innovation products needed by customers can be in the form of development of existing product lines, as well as products that are completely new to the market. Innovation is also one of the strategies to improve performance. Silvadas and Dwyer (2000), explain that a company must pay attention to the learning orientation and market orientation, due to knowledge of market orientation and learning orientation is the key to the success of product innovation that will be generated.

Kohli and Jaworski (1998) defined market orientation to create market intelligence so that organizations can understand the needs of consumers today and in the future. While the concept of learning orientation according to Baker and Sinkula (1999) is to increase the organizational value that can influence companies to create knowledge about market-oriented and learning-oriented cultural processes. Hurley and Hult (1998) state that the ability to create innovative ideas should be part of organizational culture.

Based on the background, there is a fundamental question which is how to improve the performance and build competitiveness of private universities, especially in the market (customers), commitment to the learning and the ability to innovate as an effort by companies to create highvalue products. Based on these explanations, it is interesting to conduct research that tries to link the market orientation, organizational learning, and innovation as a basis for increasing competitiveness.

\section{Market Orientation}

Uncles (2000) defined market orientation as a process and activity related to customer creation and satisfaction by assessing customer needs and wants continuously. The application of market orientation will bring an increase in performance for the company. Narver and Slater (1995) stated that market orientation consists of three components, namely customer orientation, competitor orientation, and inter-functional coordination. Customer orientation and competitor orientation including all activities are involved in obtaining information about buyers and 


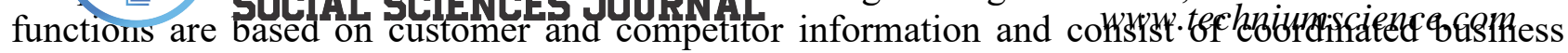
ventures.

Thus, it can be seen three main things namely (1). Market orientation is market research to all companies to find out the needs of current and future customers (intelligence generation). (2). Spread throughout the company (intelligence dissemination). (3). Liability for market intelligence. Market orientation is valuable for the company because it can help the company to focus on attention: first, gathering information about the needs of the target customers and the competitor's capabilities continuously. Second, market orientation can use this information to create customer value on an ongoing basis (Slater \& Nerver, 1995).

Market orientation is seen as important because it is part of the business culture, it facilitates companies in achieving sustainable competitiveness by creating superior customer value. Another reason that makes market orientation important is its relationship with business performance.

Market orientation is very effective in gaining and maintaining competitive advantage, which starts with planning and coordination with all parts of the organization to satisfy the needs and desires of consumers. Therefore, market orientation must emphasize the importance of analyzing the needs and desires of target markets more efficiently and effectively compared to competitors in an effort to achieve competitiveness. The emphasis of market orientation on competitiveness is based on identifying customer needs so that each company is required to be able to answer the needs of consumers both through the creation of new products or the development of existing products, in order to create superior value for consumers in a sustainable and able become the main capital for the company to win the competition.

\section{Innovation orientation}

Innovation is a company's mechanism to adapt to a dynamic environment. This idea was revealed by Farrel (2000); Day (1994); Dickson (1996); and Stata (1992). While Stata (1989) and Hurley \& Hult (1998) stated that learning orientation is the key to innovation. Therefore, companies are required to be able to, learn to develop or be able to create new thoughts, new ideas, which offer innovative products and improve services that can satisfy customers.

According to Damanpour (1991), innovation is an introduction to equipment, systems, laws, products or services, new production of technological processes, a structure or a new administrative system, or a new planning program for an organization to adopt. Damapour Research (1991) classified innovations into several types, including: administrative innovation, technical innovation, product / service innovation, process innovation, radical innovation, incremental innovation.

Administrative innovation relates to organizational structures and administrative processes that indirectly relate to the basic activities of the work of an organization and it also relates directly to the management of the organization. Technical innovation relates to technological products, services, and production processes. Product innovation is a new product or service that was introduced to outside users or because of market needs.

Process innovation is a new element introduced in a company's production or service operations, the input of raw materials, job specifications, work and information, and equipment used, for the production of a product or making a service.

Radical innovation is a service product that was not available in the past, or in the form of a new system (new delivery system) for existing service products. Included in this first category are 1) Major innovation, a service innovation that is completely new to the market (it has never been in the market). It is usually highly controlled by computer-based information and technology; 2) Startup business, is a new service in the market that has been served before; 3) New service for the market presently, new products offered to exist customers, even though these services may have been provided by other organizations.

Incremental innovation is changes to existing service products, which are considered as improvements. These changes can be in the forms of 1) Service line extension, an increase or expansion of existing service lines; 2) Service improvements, are changes to the service features 


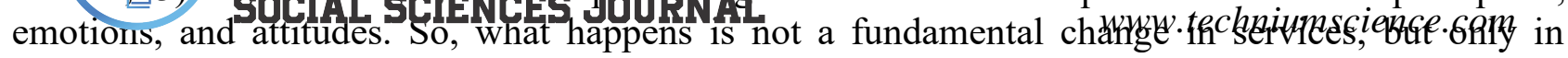
appearance.

\section{Learning orientation}

Organizational learning is the process of gaining individual and group knowledge that is willing to apply it to their work in making decisions and influencing each other as dynamic capabilities as competitiveness resources (Khandekar and Sharma, 2006). Organizations that are willing to carry out experiments and are able to learn from their experiences will be more successful than organizations that do not (Wheelen and Hunger, 2002). To achieve and maintain competitiveness in a rapidly changing business environment, organizations must be able to increase their learning capacity (Marquardt, 1996).

Organizational learning according to Senge (1990) is one of the skills that must be possessed by leaders. In organizational learning, superiors continually provide opportunities for each member of the organization to learn and by learning the abilities will increase. This is in line with the opinion of Senge (1990), that organizational learning has a strong orientation to human resources, by stating "people continually expand their capacities to create the results they desire, where new and expansive patterns of thinking are nurtured, where collective aspiration is set free, and where people are continually learning how to learn together. "Organizational members share information, create organizational memory in forming shared beliefs, assumptions and norms, which will guide the actions of individuals and organizations. Organizational ability to learn is determined by the relevant ability to process information, communication, transfer of knowledge, coordination between business units, and the ability to build trusted relationships with consumers and negotiations. As expressed by Goh and Peter, (2008) companies that are willing to experiment and are able to learn from experience will be more successful than companies that do not.

Khandekar and Sharma (2006) used 9 items to measure learning related to HR activities, namely: human resource strategies, training and learning, performance appraisal, rewards and incentives, supportive conditions, work teams, knowledge creation, quality of management, and flexibility. Senge (1990) in his book The Fifth Discipline: The Art and Practice of the Learning Organization, built five key disciplines of organizational learning. According to Sange, the five disciplines, namely the system of thinking, mental models, personal mastery, team learning and building shared vision are "technological components" or very important dimensions needed in building organizational learning. Marquardt (1996) then adds another important dimension in building organizational learning, namely dialogue. According to Marquardt (1996) to realize the organizational learning process there are six dimensions needed, namely systems thinking, mental models, personal skills, teamwork, sharing a shared vision, and dialogue.

\section{Organizational performance}

Company performance is the level of achievement of company performance measured in the form of work results or performance outcomes (Rue \& Byard, 1997). In Cravens theory (1996) Indicators of performance measurement are satisfaction, loyalty, market share and profitability. Market share is a measurement of marketing performance or operational performance that can distinguish between winners and losers (Szimansky, 1993). If the company's market share increases, it means that the company can outperform its competitors, if the company's share market decreases, it can be said that the company is losing out to its competitors. Measurement with overall market share is widely used because it only requires information about total sales (Kotler, 2003). Ferdinand (2000) revealed that marketing performance would be measured using sold units (increased sales volume), customer growth and customer turnover rates to further state marketing activities. The ability to generate profits is one indicators in measuring performance. Profit is used because of the breadth of using these benchmarks to measure performance in previous studies which are a reflection of the success of marketing performance. 


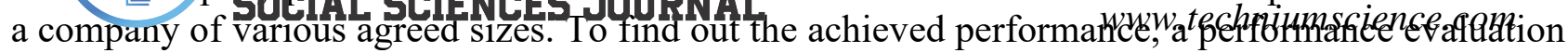
is carried out. The word assessment is often interpreted as the word assessment. While the company's performance is something that is produced by a company in a certain period with reference to the standards set. Thus the company's performance assessment implies a process or evaluation system regarding the implementation of the work capabilities of a company (organization) based on certain standards (Kaplan and Norton, 1996; Lingle and Schiemann, 1996).

In a broader perspective of performance appraisal, Hansen and Mowen (1997) state that there are two types of performance appraisal activities namely; financial and non-financial. This measurement is designed to estimate how the performance of activities and the final results achieved.

\section{Competitive advantage}

Ferdinand (2000) states that in a competitive market, a company's ability to produce performance, especially financial performance, highly depends on the degree of competitive advantage. To preserve its existence, the company's competitiveness must also be sustainable, because basically, the company wants to preserve its existence. Sustainable competitiveness is the company's strategy to achieve its ultimate goal, namely performance that produces high profits. That is, sustainable competitiveness is not the final goal, but as a means to achieve the company's final goal, which is to improve company performance. Kotler and Armstrong (2003) define competitiveness as an advantage over competitors obtained by offering lower values or by providing greater benefits because of higher prices. Meanwhile, according to Porter (2004), competitive advantage is at the heart of the company's performance in a competitive market, but after decades of great expansion and prosperity, many companies have lost sight of competitiveness in the struggle to develop more in the pursuit of diversification.

To measure competitiveness in research Day and Wersley (1988) states there are two steps in achieving competitiveness; first is the superiority of resources consisting of superior expertise and excellence in raw materials, then the second is the superiority of position consisting of relative cost advantages and value advantages for customers. Referring to the research of Day and Wersley (1988 in Bharedway 1993), the competitiveness indicator that used is valuable which is different from the others that is not easily replaced.

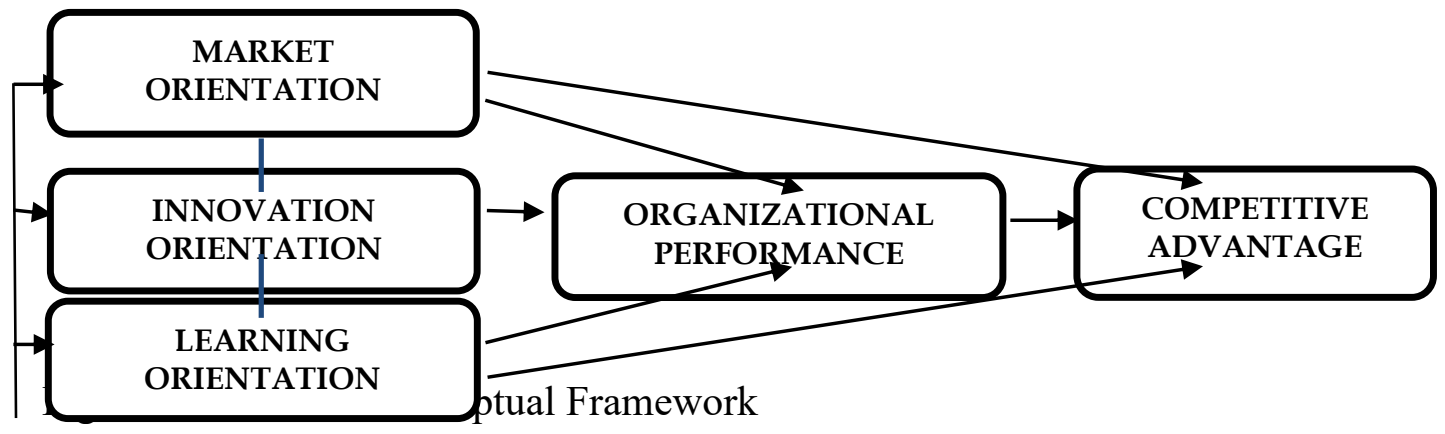

Research Hypothesis:

H1: Market orientation has a positive effect on performance

$\mathrm{H} 2$ : Market orientation has a positive effect on competitive advantage

H3: Innovation orientation has a positive effect on performance

H4: Innovation orientation has a positive effect on competitive advantage

H5: Learning orientation has a positive effect on organizational performance

H6: Learning orientation has a positive effect on competitive advantage

\section{Research Methods}

Types of research 


\section{TECHNIUM}

tune $r$ f research

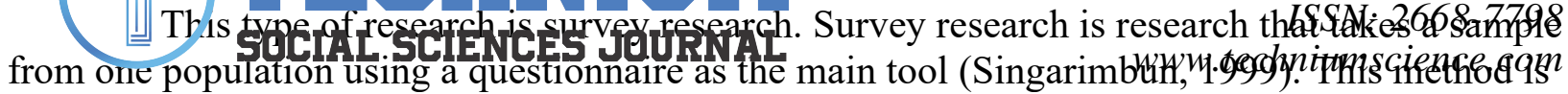
also called the questionnaire method because in order to obtain the data a series of questions are arranged in a list.

\section{Population and Sample}

The population in this study was the leaders of accredited private universities in Bengkulu province, the total is 17 private universities. The samples used in this study were 127 samples consisting of university leaders, deans, and heads of study programs.

\section{Data analysis method}

The model used in this study is structural equation modeling (SEM) to determine the causal relationship between latent variables contained in structural equations.

\section{Results and Discussion}

The results of the analysis can be seen in the following figure:

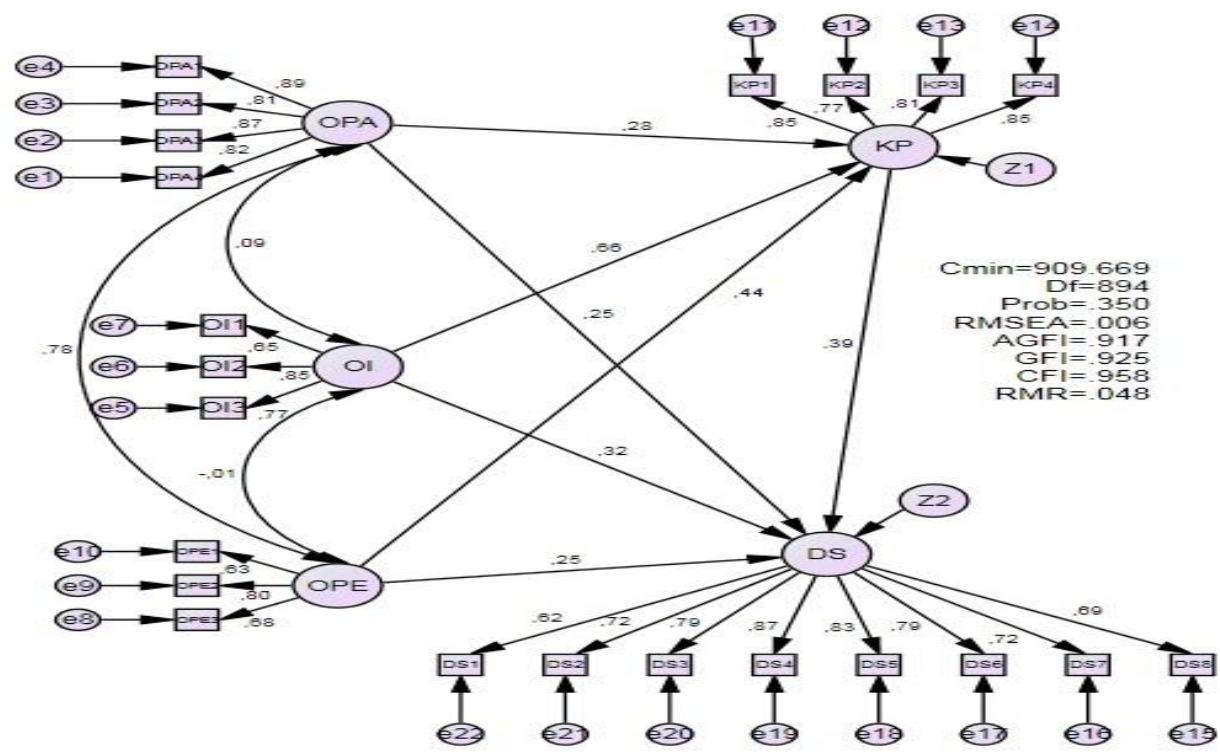

Figure 2: Effect of Market Orientation, Innovation Orientation, and Learning Orientation on the Performance and Competitiveness of Private Universities in Bengkulu Province.

\section{Market Orientation and Marketing Performance}

Cravens (2000) views market orientation as a business orientation, so that customers are used as vocal points and the totality of the company's operations. This opinion is reinforced by Slater \& Narver (1995) which states that the concept of market orientation is valuable to the company because it can help the company to focus attention in gathering information about the needs of target customers and the ability of competitors continuously, as well as using that information to create sustainable customer value independently.

The results of hypothesis testing prove that market orientation has a positive and significant effect on marketing performance. These results provide an indication that the implementation or creation of a good and conducive market orientation through information gathering, dissemination of institutional information, staff information dissemination, and response to the labor market will make private universities in Bengkulu Province have a good customer perspective, financial perspective, development perspective learning, and an internal reputation development perspective that can be a reflection of marketing performance. This finding shows that the better the market orientation of private universities, the better the marketing performance of private universities in Bengkulu province. 


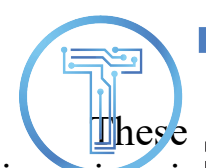
conclude that market orientation appears to provide strong explanations for strategies and strategies related to performance.

\section{Market Orientation and Competitive Advantage}

In this study, market orientation directly influences the competitive advantage of private universities in Bengkulu Province. Gathering information in private universities will form a competitive advantage. These results provide evidence that information gathering, staff information dissemination, and institutional information dissemination have a positive direct impact on the competitive advantage of private universities in Bengkulu Province.

These results support the research of Akimova (1999), which says that market orientation has a positive effect on competitive advantage. In addition, these results also support the research of Bharadwaj (1993), which states that a corporate culture that emphasizes the importance of companies to pay attention to the market will lead to strengthening the company's competitive advantage.

Based on the results of testing intervening variables in this study, it is proven that the influence of market orientation on competitive advantage through marketing performance is significant and positive. These results can also indicate that marketing performance is able to complete mediation of the influence of market orientation on the competitive advantage of private universities in Bengkulu Province.

\section{Innovation and Marketing Performance Orientation.}

Innovation is a management function that has a positive effect on marketing performance. This view is in line with Jin.K.Han Namwoon Kim and Rayendra K Srivatava (1998) who explain that innovation is a system that enhances the company's role in marketing performance, and focuses on emphasizing the need for further research on the role of innovation to produce good marketing performance, specifically regarding technical innovation and administrative innovation as well as how its implementation on market performance has an impact on competitive advantage that can be created.

Based on the results of the significance test conducted in this study, it shows that the orientation of innovation provides positive and significant results on marketing performance. This finding indicates that PTS is quite responsive to the orientation of innovation so that a positive relationship is found between the teaching and learning process, curriculum improvement, and improvement of the administrative system with marketing performance. The current marketing performance is quite capable of being influenced by an innovation orientation, which contains at least an overview of the current and future academic conditions of the tertiary institution.

The results of this study support the research of Droge and Vickrey (1994), who say that innovation is positively related to the company's competitive advantage. Companies that implement innovations in products as well as distribution and administration systems have advantages in terms of product design and ease of payment and distribution. In addition, these results also support the research of Bharadwaj (1993) which states that the company's ability to innovate continuously will keep products in accordance with the wants and needs of customers.

Innovation is a way to build and develop private tertiary institutions through the introduction of new technologies, new applications in the form of curriculum, services, new market development in the form of developing study programs or introducing new study programs. The development of information technology that is increasing rapidly in the era of the industrial revolution 4.0 must be a concern for university circles. With mastery of information technology can support all aspects of university services, so that improving the quality of Indonesian tertiary institutions can be achieved.

\section{Learning Orientation and Marketing Performance}


Hypothesis testing results reveal that learning orientation has a positive and significant effect on marketing performance. These results indicate that the marketing performance of private tertiary institutions depends on the orientation of learning possessed by tertiary institutions. Positive influence arises because the orientation of learning is considered an investment, the key to development, and is able to have a good impact on the marketing performance of private tertiary institutions.

The results of this study, if confirmed by several opinions and studies that examine the relationship between learning orientation and marketing performance (Day, 1999; Nobel et.al 2000, Farrel, 2000; Dickson, 1996; Stata, 1992), it appears that the results of this study are in line with these studies. This explains that the level of expertise of private universities in terms of learning orientation will affect the marketing performance of private universities.

The learning orientation component owned by private universities is related to commitment to learning, shared vision, and various views so that the success of private universities can be achieved quickly if leaders and employees continue to learn from market needs and customer needs. The leadership always motivates lecturers and education personnel to continue to be creative, open to reviewing developments in the market, and to encourage improvement in the development of human resources by participating in trainings, seminars, workshops, and other activities in an effort to improve the quality of human resources. Good collaboration between leaders and employees will have an impact on the progress and development of institutions, which in turn can improve welfare.

\section{Learning Orientation and Competitive Advantage}

This study shows that there is a significant positive relationship between learning orientation and competitive advantage in private tertiary institutions. These results support Ardekani and Nystrom's research in (Beal, 2000, p.30), Menon et al (1999, p.25) which states that elements of the competitive environment should be studied further because industry failure in achieving sales growth stems from management inability to analyze the changes that occur in the industrial competition environment.

Based on the description, it can be said that this study illustrates that the learning orientation possessed by a private universities in Bengkulu Province will directly affect the competitive advantage of the private universities, where the learning orientation is believed to provide a different value from its competitors.

The results of the analysis in this study indicate that the learning orientation possessed by universities is a determinant of direct competitive advantage, as well as a determinant of the competitive advantage of private universities in Bengkulu Province if it is through marketing performance as a mediation.

\section{Marketing Performance and Competitive Advantage}

From the results of the hypothesis testing the effect of marketing performance variables on the competitive advantage, variables revealed that Marketing Performance proved to have a positive and significant effect on the competitive advantage of private universities in Bengkulu Province. This shows that the achievement of a university's competitive advantage is highly dependent on the marketing performance of private universities. This study also managed to find a positive and significant effect between marketing performance and competitive advantage.

Porter (1996) in Competitive Strategy: Techniques for Analyzing Industries and Competitors, explains that performance is the 'heart' of competitive advantage in a competitive market. And how companies use strategies to adapt to their environment is the meaning of a strategic orientation. Marketing performance in a strategic management system occupies a crucial position. In a dynamic and complex business environment, companies need to arrange marketing performance. At the stage of marketing performance, strategic options are described to realize the organization's vision and mission into strategic objectives. 

that the marketing performance of private universities will have an impact on the competitive advantage of private tertiary institutions. The results of this study prove a positive relationship between marketing performance and competitive advantage. The better the performance of private universities carried out will increase competitive advantage.

Currently, digitalization has become the main spirit in the service of private universities, in various aspects, it is expected that the leaders of private universities can commit to create quality, competitive and innovative private universities to face the current digitalization era.

\section{Conclusions and recommendations}

\section{Conclusion}

Based on the results of the analysis, hypothesis testing, and discussion of research on the competitive advantage of private universities in Bengkulu Province, the conclusions can be drawn as follows:

1. Private universities will gain a competitive advantage if they can maximize their performance. Through market orientation information can be obtained about customer wants and needs, through organizational learning private universities gain knowledge and apply it to the learning process in coordinative ways through teamwork, and innovate with regard to new planning programs tailored to the college private sector through the latest information systems.

2. Changes in the world are now entering the era of the industrial revolution 4.0, where the pattern of human life is based on information. Thus, preparing quality graduates who are able to compete globally, as well as mastering technological development is important for the future of the nation. The industrial revolution 4.0 is closely related to innovation created by quality resources, hence private universities can answer the challenges to face technological advances and competition in the world of work. In creating innovative and adaptive resources for technology, learning facilities and infrastructure are needed which will be able ultimately to produce graduates who are skilled in the aspects of data literacy, technology literacy and human literacy.

\section{Suggestion}

Based on the discussion and conclusions of the study, the suggestions and recommendations that can be given in this study are:

In order to gain competitive advantage, private universities can develop marketing strategies through the following steps: (a) Leaders always pay attention to market orientation by focusing on the quality of services provided by competitor universities. This is done as an evaluation material for improvement. (b) Leaders must be able to increase their learning capacity, by providing opportunities to increase knowledge about better ways of working through education and training, besides developing themselves in the fields of knowledge and technology. (c) Continuously developing or innovating in relation to academic and non-academic systems.

\section{References}

[1] Akimova, I. (1999). Development of Market Orientation and Competitiveness of Ukrainian Firm. European Journal of Marketing, 34(9), 1128-1146.

[2] Ardekani \& Nystorm. (2002). Designs for Environmental Scanning Systems:Tests of Contingency Theory. Journal of Small Business Management, 38(1), 27-47.

[3] Baker., Sinkula. (1999). "The Synergistic Effect of market oriented and learning organization on organization performance". Journal of The Academy of Marketing Science. Vol. 27, P. 411-427 
[5] Bharadwaj,Sundar G, P.R.Varadarajan, Fahly, Jihn. (1993). Sustainable Competitive Advantage in Service Industries: A Conceptual Model and Research Propositions.Journal of Marketing, Vol.57,Oktober,p.83-99.

[6] Chuang, S.H. 2004. A Resource-based view on Knowledge manufacturing Capability dan Competitive advantage: An Empirical Investigation. Expert Systems with Applications, 27, pp. 459-465.

[7] Cravens, W, David, Niegel, R., Piercy. (2009). Strategic Marketing (9th edition). New York: Mc Graw-Hill International

[8] Cunningham, J.B., and P. Gerrard, 2000. Characteristics of Well Performing Organisations in Singapore, Singapore Management Review, Vol. 22, No.1, pp.35-64.

[9] Damanpour, F. 1991. Organizational innovation: a meta analysis of effects of determinants and moderators. The Academy of Management Journal, Vol. 34, No. 3, pp. 555-590.

[10] Day, G.S. (1994). The Capabilities of Market Driven Organizations. Journal of Marketing, 58 (October):37-52

[11] Droge, C.\& Vickrey, Shownee. (1994). Source and Outcomes of Competitive Advantage: An Explanatory Study in The Furniture Industry. Decision Sciences,p.669-689.

[12] Farrel, Mark. A. (2000). "Developing a Market Oriented Learning Organization “ Australian Journal of Marketing Mangement. Vol 25.P.202-222

[13] Ferdinand, A. 2006. Metode Penelitian Manajemen, Pedoman Penelitian untuk Penulisan Skripsi, Tesis dan Disertasi Ilmu Manajemen, Badan Penerbit Universitas Diponegoro.

[14] Goh, C.S., and Peter, R. 2008.The organizational performance of learning companies: A longitudinal and competitoranalysis using market and accounting financial data, The Learning Organization,Vol. 15, No. 3, 225-239.

[15] Han, J. K., Namwoon Kim, and Rajendra K. Srivastava. (1998). "Market Orientation and Organizational Performance : Is Innovation a Missing Link?", Journal of Marketing 2.

[16] Hurley, RF.,\& Hult, TM (1998). Innovation, Market Otientation, and Organization Learning; An Integration and Empirical Examination, Journal of Marketing. 62(10), 42-45.

[17] Khandekar, A., and A. Sharma. 2006. Organizational Learn- ing and Performmance: Understanding Indian Scenario in Present Global Context, Education and Training, Vol.48, No.8/9,pp.682-695.

[18] Kohli, A. K., and Jaworski, B. J. (1998). Market Orientation : The Construct, Research Propotition and Managerial Implication, Journal of Marketing, Vol. 54, pp.1-18.

[19] Kotler, P., dan Gary, A. 2004. Prinsip-Prinsip Pemasaran, Edisi, Terjemahan: Damos Sihombing. Jakarta: Erlangga.

[20] Lings, I., and Greenley, G. 2009. The Impact Of Internal and External Market Orientations on Firm Performance. Journal of Strategic Marketing, 17(1). pp. 41-53.

[21] Marquardt, M.J. 1996. Building the Learning Organization. NewYork: McGrawHill Companies, Inc.

[22] Narver \& Slater, S.F. 1995, Marketing Orientation and Organizational Learning, Journal of Marketing, Vol. 58, No. 3, pp. 63-74.

[23] Njuguna, I.J. 2009. Strategic Positioning For Sustainable Competitive Advantage: An Organizational Learning Approach. Journal of Business Management: Vol. 2, Issue 1. pp. $32-43$.

[24] Penrose, E.T. 1959. The Theory of the Growth of the Firm, 7rd Edition. New York: Oxford University Press.

[25] Peteraf, M.A. 1993. The Cornerstones of Competitive Advantage: a Resource-Based View, Strategic Management Journal, Vol.14, No. 3, pp.179-191.

[26] Porter, M.E. 2004. The Competitive Advantages of Nations, Harvard Business Review. 
[28] Schiffman, L.G., dan Kanuk, L.L. (2008). Consumer Behaviour, 7th ed., New Jersey: Pearson Prentice Hall.

[29] Senge, P.M. 1990. The Leader's New Work: Building Learning Organizations, Sloan Management Review, Fall 32 (1),pp.7-23.

[30] Singarimbun, M., dan Sofian, E. 2005. Metode Penelitian Survei. Jakarta: LP3ES.

[31] Song, X.M., dan Parry, M.E. 1997. The Determinants of Japanese New Product Successes, Journal of Marketing Research, Vol.XXXIV Februari.

[32] Sugiono. 2006. Metode Penelitian Administrasi. Bandung: Alfabeta,

[33] Uncles, M. 2000. Market Orientation. Australian Journal of Management. Vol.25, No.2.pp. 1-15.

[34] Wang, Y., and H. Lo. 2003. Customer focused Performance and the Dynamic Model for Competences Building and Leveraging: A Resource-based View, Journal of Management Development, Vol.22, No.6, pp.483-526.

[35] Wheelen, T.L., and J. David, H. 2002. Strategic Management and Business Policy. Eighth Edition. New Jersey: Prentice-Hall. 